\title{
Personality determinants of health behaviours of merchant navy officers
}

\author{
Mariusz Lipowski ${ }^{1}$, Małgorzata Lipowska ${ }^{2}$, Aleksandra Peplińska ${ }^{2}$, Maria Jeżewska $^{3}$ \\ ${ }^{1}$ Department of Health Psychology, Gdansk University of Physical Education and Sport, Gdansk, Poland \\ ${ }^{2}$ Institute of Psychology, University of Gdansk, Poland \\ ${ }^{3}$ Institute of Maritime and Tropical Medicine, Medical University of Gdansk, Poland
}

\begin{abstract}
Background and aim: An individual's health behaviours are highly correlated with selected areas of their personality as well as their values, needs and goals. However, this relationship may be modified by a number of objective factors associated with the individual's functioning, lifestyle or occupational activity. The main objective of the presented study was to investigate the relationship between personality profiles and health behaviours of merchant navy officers.

Materials and methods: The influences of personality on health behaviours were additionally compared between two groups: mariners and managers. Thirty-two seafarers of an officer rank and 45 managers aged between 29 and 48 took part in the study. Three research tools were used: NEO-Five Factor Inventory, Health Behaviour Inventory and Inventory of Physical Activity Objectives.

Results and conclusions: Results suggest that selected personality variables are significant predictors of individual aspects of health behaviour, however the strength of their influence may differ, depending on the peculiarities of the performed work.
\end{abstract}

(Int Marit Health 2014; 65, 3: 158-165)

Key words: seafarers, personality, health behaviour, physical activity

\section{INTRODUCTION}

In highly industrialised countries, the role of permanent stress, especially related to the occupational activity is increasingly emphasized as a factor involved in the rise of morbidity in autoimmune diseases (e.g. Hashimoto, Graves-Basedov), heart diseases, rheumatoid arthritis, diabetes, ulcerative colitis, but also psychological problems such as depression and dependence on alcohol or psychoactive substances [1].

Mariners are one of the professional groups at the highest stress risk. The work environment at the sea is hard to compare with any such environment ashore, which is a result of a number of harmful factors concentrated in a small area. This includes chemical, physical and biological factors associated with the peculiarities of working at sea [2]. Analysis of subject literature allows one to pinpoint a number of sources of stress that usually include: deprivation of a number of basic needs resulting from the prolonged separation from family and friends $[3,4]$, social threats resulting from the tension of being in a closed group of people [3], onerous physical conditions of work - rocking, vibrations, noise, changes in climate and time zones [6], mental and physical overload associated with performing work in difficult weather conditions, for example during storms [7]. The period of occurrence of these stress factors as well as their chronic character determines the perception of constant emotional tension by most seafarers. This tension has an increasing tendency throughout the period of the cruise $[6,8]$. Long-term isolation at sea is a very important factor causing this tension. It is considered a particular kind of an extremely difficult situation associated with a (more or less) lengthy disruption in the optimal levels of stimulation $[9,10]$. Separation from family and friends is often mentioned by the seafarers themselves as the biggest nuisance

Dr Maria Jeżewska, Clinic of Occupational and Internal Diseases, Institute of Maritime and Tropical Medicine, Medical University of Gdansk,

ul. Powstania Styczniowego 9B, 81-519 Gdynia, Poland, tel: +48 58349 19 32, e-mail: mariajez@gumed.edu.pl 
and stressor. It is an additional factor, strongly influencing the subjective perception of quality of life $[3,11]$. The subjectively experienced stress often results in a decrease in the overall psychological wellbeing index of the analysed group, and hence it may also stimulate a decrease in the subjective assessments of quality of life, spreading to other areas of acting and functioning [10,12,13]. Work under such stressful conditions has a negative impact also on the health of the seafarers [4]. The most commonly reported health problems include: sleep and eating disorders [4], coronary disease, but also Post Traumatic Stress Disorder (which particularly affects the seafarers that experienced exposure to extreme threats to life and health) [8], and suicidal thoughts and attempts [8]. Understandably, the intensity of the stressors and the health and psychological risks depend on the character of the work at sea [6]. The analysis of deaths at the sea, performed by Jaremin [2] between 1960 and 2000 , revealed that $80 \%$ of deaths of mariners from merchandise navy were caused by external factors - mainly accidents such as drowning, going missing, mechanical injuries, electrocution, and suicides. The remaining $20 \%$ were caused by health problems, mainly heart attacks and strokes. The multiplicity of stressors in the work of seafarers may cause: accumulation of fatigue, sleeping disorders, interferences in the operation of the nervous system, attention and alertness disorders (that encourage errors and accidents at work), susceptibility to food poisoning, infections, arrhythmia, circulation problems, neurosis and other psychosomatic problems [2]. It is important to mention that these risks are often associated with low physical activity (PA) during the time at sea - lack of everyday physical training, little opportunity to practice sports - all of which may lead to cardiac atherosclerosis, obesity, hypertension, and diabetes [2]. The analysis of literature regarding the health of seafarers indicates a significant threat of cardiac inefficiency and acute coronary incidents [2]. Alcohol and nicotine-related disorders, neuroses, personality disorders, respiratory tract diseases are also commonly listed. The health of individual members of the crew, their fitness and ability to work, directly influence the safety of the whole crew, and the risks of catastrophes and collisions at the sea. Due to this, awareness about the importance of health of seafarers is rising, together with awareness about the importance of health behaviours and prevention, which are lifestyle related. One needs to note that the recent changes in the labour market have resulted in withdrawal of medical staff from ships, and therefore placing the responsibility onto the seafarers who have to care for their own health, engage in medical self-help, and self-rely to cope in emergency situations [2]. This refers especially to the officers of merchant navy, a specific group of seafarers who are also managers [14]. Apart from the stressors related to working at sea, they are also affected with stressors resulting from managing a group of people [15]. In this regard, their tasks are similar to those of other occupational groups, e.g. managers. Stress among managers is mostly caused by the responsibility for teams of subordinates, implementation of projects or the budget. Additionally, the ever changing labour market requires a continuous upgrade of technical knowledge and skills necessary to manage a team of people. Moreover, managers' actions are continually assessed, which causes a significant increase in their levels of tension and stress [16]. Operating in such conditions may have negative health consequences and influence the psychophysical well-being of workers, which negatively feeds-back to the effectiveness of the team and the organisation $[17,18]$. In the case of the officers of merchant navy, we not only speak about managing a team of people, but also managing the ship, responsibility for people and equipment in a high stress environment. A burden for the organism that is both physical and psychological (resulting from the separation from friends and family as well as isolation and deprivation of needs). The data about morbidity and health problems among mariners suggests that officers comprise a high percentage of those experiencing heart attacks, or reporting problems with circulation or respiration [6].

Health, next to successful social relations, is one of the most important indicators of quality of life. In the past 10 years Poles have been ascribing increasing meaning to health [19]. Paradoxically, only 1 in 10 citizens of Europe actually pays adequate attention to health [20]. The determinants of health can be divided into biological and social. While individuals may have little influence on the biological factors, the social factors are highly correlated to their activity, which includes: lifestyle, psychological resources, social relations, economic conditions, and natural environment [21]. Psychologists emphasize the role of lifestyle: a resultant of individual preferences as well as behavioural patterns and conditions of life determined by psychological, socio-economical, and cultural factors.

Lifestyle is associated with health in two ways. It influences health directly through diet, exposure to harmful agents or pathogens as well as stress, but also indirectly, through health behaviours [22]. Many researchers believe that an individual's lifestyle can radically reduce morbidity; therefore it is a dominant factor in achieving prospective health goals [23].

Despite the objective indications for undertaking prohealth behaviours, still, a high percentage of society does not engage in such activities [20]. That is why psychological predictors of pro-health behaviours are of research interest. Research in the personality psychology suggests that personality features, and personal goals are important factors 
in shaping pro-health behaviours [24]. The popularity of the Five Factor Personality Model by Costa and McCrae [25] has been growing in recent years among researchers. The dimensions listed by the authors include: Neuroticism, Extroversion, Openness to Experience, Agreeableness, and Conscientiousness. Personality variables are related to the subjective perception of psychological wellbeing. Studies by the authors of the model suggest a negative correlation between neuroticism and a sense of satisfaction as well as positive relations between extroversion along with openness to experience, and overall satisfaction with life [26]. Many recent studies confirm the relationship between personality and health behaviours. It is worth noting that health behaviours include pro-health behaviours that positively affect health, but also anti-health behaviours that can pose a direct or long-term threat for health [23].

Meta-analyses of research suggest a clear correlation between the dimensions of personality and both pro- and anti-health behaviours [27]. Numerous reports indicate a positive correlation between conscientiousness and the undertaking of pro-health behaviours (negative with the anti-health behaviours) [28]. Conscientiousness is a dimension characterising the levels of organisation, persistence and motivation of an individual during goal-oriented actions, as well as the attitudes towards social norms, and control over compulsive behaviours [25]. High levels of conscientiousness entail self-discipline, engagement in care for one's health through PA, healthy diet, and restraining from smoking, drinking alcohol as well as the use of psychoactive substances [28, 29].

Openness to experience is most often associated with prophylactic behaviours such as regular control of one's health and acting according to doctors' recommendations [30]. This feature describes the intensity of cognitive openness, tolerance for novelty and is associated with general intelligence and creativity [25]. The inclination towards novelty is listed as a factor increasing the risk of experimenting with psychoactive substances or engaging in risk-behaviours [31]. Agreeableness includes several features associated with interpersonal harmony, such as: honesty, trust, compassion and respect for others [25], therefore it is usually associated with higher levels of engagement in pro-health behaviours, especially if they concern the whole socially significant reference group e.g. family [32, 33]. Extroversion is a dimension characterising the quality and quantity of social interactions, as well as the levels of activity, energy and ability to experience positive emotions [25] and is usually regarded as a predictor of good health [27]. At the same time, it is associated with the tendency to undertake risky behaviours such as: alcohol abuse, use of psychoactive substances [34], risky sexual-behaviours [35], extreme sports [36, 37]. Neuroticism has the most complex and varied relationship with health. On one hand, high neuroticism, entailing high susceptibility to negative emotions such as fear, embarrassment, dissatisfaction, anger, guilt, and sensitivity to psychological stress [25], is associated with higher susceptibility to various diseases and a shorter life-span [38]. On the other hand, higher levels of anxiety may lead to increased concern about one's health and quicker identification of disease symptoms, sticking to healthy diet and engaging in PA [27, 39, 40].

The relationship between personality and health and engaging in health behaviours seems to be undeniable. Of course, it is modified by objective indices associated with the necessity to undertake activities aimed at improvement or sustaining of health. This is why it seems appropriate to look for relations between the particularities of functioning of an individual resulting from their occupation and the personality variables. The goal of the presented study was to look for personality determinants of health behaviours among the officers of the merchant navy and a comparative analysis of those determinants with a control group of managers doing their work ashore.

Taking the above into account, it can be assumed that personality profiles, and the levels of engagement in prohealth behaviours will be similar among the examined mariners and managers. In both groups the personality profiles should determine pro-health behaviours. However this impact will be different among merchant navy officers, than in case of individuals who also bear managerial functions, but with a land-based work environment.

\section{MATERIALS AND METHODS}

Thirty-two Polish officers took part in the study. Forty-five managers of private enterprise in Poland formed the control group. Subjects from both groups were of similar age - between 29 and $48(\mathrm{M}=37.87, \mathrm{SD}=7.11$, $t=0.53, p=0.596)$ and had at least 7 years of experience in management.

All the participants were examined with NEO-Five Factor Inventory, Health Behaviour Inventory and Inventory of Physical Activity Objectives.

NEO-Five Factor Inventory (NEO-FFI) by Costa and McCrea, Polish adaptation by Zawadzki et al. [41], determines principal personality dimensions, the so-called Big Five, i.e. Neuroticism, Extroversion, Openness to Experience, Agreeableness and Conscientiousness.

Health Behaviour Inventory (HBI) by Juczyński [42] is used for evaluation of involvement in health-seeking practices. The answers are analysed in 4 categories of health-seeking behaviours: Proper Nutrition Habits, Prophylactic Behaviour, Health Practices and Positive Psychological Attitudes.

Inventory of Physical Activity Objectives (IPAO) by Lipowski and Zaleski [personal communication] is used to 


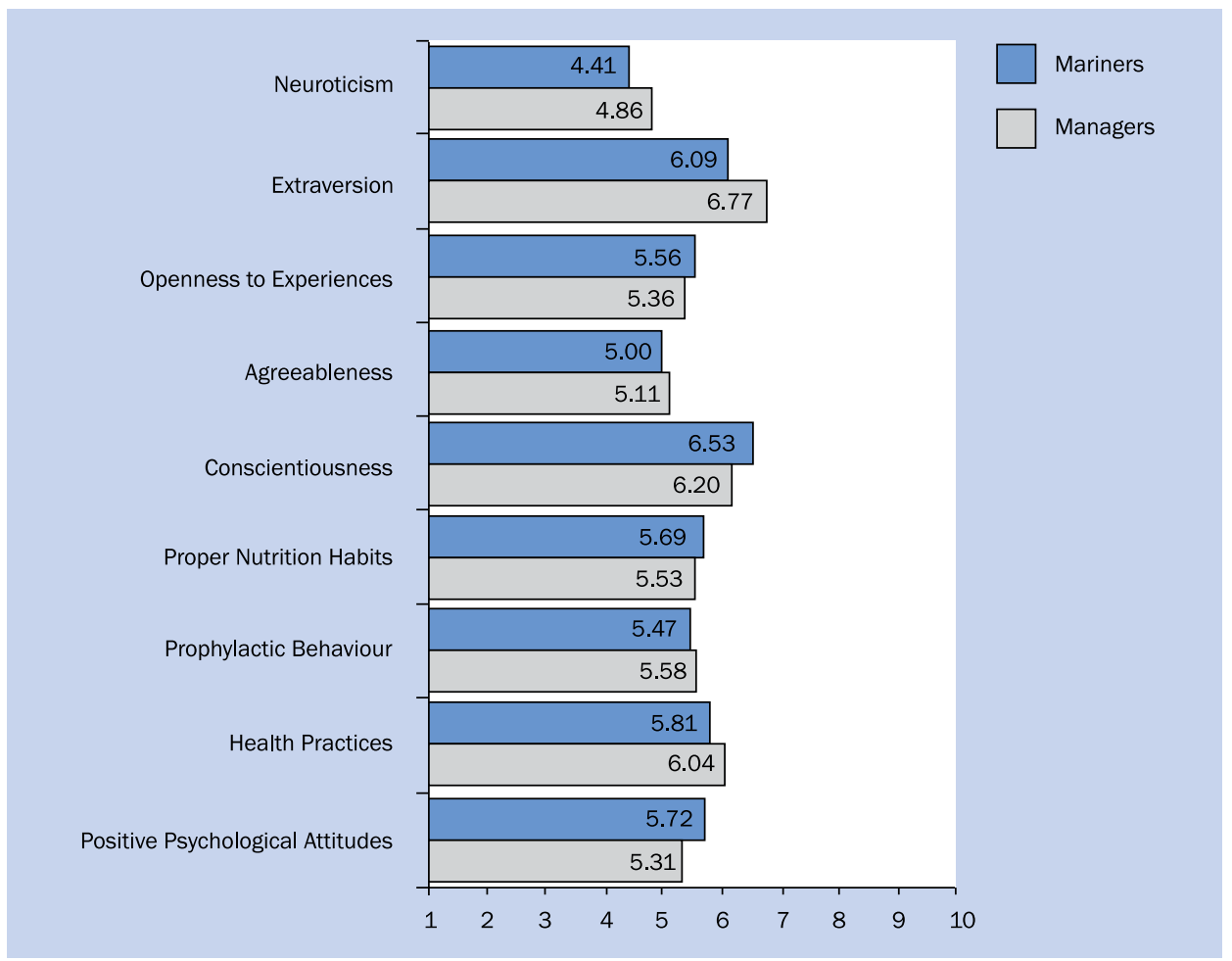

Figure 1. Personality profiles and health behaviours of mariners and managers (sten scores)

examine the motivating function of objectives leading one to undertake PA. The respondent answers questions regarding his/her involvement in competitive sports (both present and previous), and forms and intensity of his/her PA. The survey allows the analysis of objectives in terms of their dimensions (importance, expectations, conflict), as well as dimensions of action (exercise, endurance, satisfaction). The respondent is given a (multiple) choice of objectives behind his/her PA.

\section{RESULTS}

Statistical analysis was conducted with Statistica 10 software (General Linear Models, Multiple Regression, r-Pearson correlation and Indicator Variables in Regression). It was carried out in two stages. First, we compared the personality profiles and health behaviours of mariners and managers. In the second stage, we concentrated on the analysis of relationships.

\section{PERSONALITY PROFILES AND HEALTH BEHAVIOURS}

The analysis of personality profiles and health behaviours of mariners and managers revealed, that all dimensions oscillate around the average scores (Fig. 1).

No differences were observed between the groups in terms of the personality features and health behaviours. Among all the subjects, the highest levels within the Five Factor Personality Model were noted for the extraversion dimension, the lowest for neuroticism. Positive Psychological
Attitude was the dominating health behaviour. There were no differences in the declared engagement in PA - both in terms of the number of devoted hours per week $(M=4.93$, $\mathrm{SD}=3.98)$ and the number of forms of activity $(\mathrm{M}=1.56$, $S D=1.46)$. There was a high discrepancy between individual results in both dimensions of PA: subjects devoted between 1 and 20 hours to PA and they engaged in up to 6 different forms of activity. Going to the gym (36.66\%) and cycling, including stationary (37.66\%), were dominant forms of PA in both groups, followed by swimming (36.36\%), sports (24.67\%), and jogging (20.78\%).

\section{PERSONALITY AND HEALTH BEHAVIOURS OF MARINERS AND MANAGERS}

We conducted an analysis of influence of the personality traits on the dimensions of health behaviours among mariners and managers. The correlation analysis revealed many similar relationships (Table 1).

Interestingly, extroversion had a positive influence on the number of forms as well as hours devoted to a PA in both groups; however conscientiousness had such an influence only among the managers. The analysis of correlation between extroversion and agreeability, and positive psychological attitude yielded interesting results. In case of the managers these correlations are statistically stronger than among seafarers $(p=0.025$ and $p=0.005$, respectively). 
Table 1. Correlation between the results of NEO-Five Factor Inventory (NEO-FFI), Health Behaviour Inventory (HBI) and Psysical Activity $(\mathrm{PA})$ in the examined mariners and managers

\begin{tabular}{lllllll}
\hline Scale & Group & Neuroticism & Extroversion & $\begin{array}{l}\text { Openness to } \\
\text { Experience }\end{array}$ & $\begin{array}{l}\text { Agreeableness } \\
\text { Conscientio- } \\
\text { usness }\end{array}$ \\
\hline PA & & & & & & \\
Number of hours & Mariners & -0.11 & $0.40(0.025)$ & -0.02 & 0.24 & 0.05 \\
& Managers & -0.26 & $0.49(0.001)$ & 0.25 & -0.09 & $0.35(0.019)$ \\
Number of forms & Mariners & -0.10 & $0.50(0.007)$ & $0.42(0.027)$ & 0.15 & -0.16 \\
& Managers & -0.12 & $0.31(0.050)$ & $0.60(0.000)$ & 0.18 & $0.42(0.006)$ \\
HBI & & -0.07 & 0.30 & 0.33 & 0.23 & 0.00 \\
Proper Nutrition & Mariners & -0.06 & -0.01 & 0.04 & 0.04 & 0.24 \\
Habits & Managers & -0.23 & 0.24 & 0.34 & 0.27 & $-0.36(0.046)$ \\
Prophylactic & Mariners & 0.17 & -0.17 & -0.02 & -0.16 & 0.04 \\
Behaviour & Managers & -0.26 & 0.25 & -0.06 & 0.12 & 0.13 \\
Positive Psycho- & Mariners & -0.05 & 0.04 & -0.05 & -0.07 & 0.22 \\
logical Attitudes & Managers & 0.06 & $0.48(0.005)$ & 0.04 & $0.51(0.003)$ & 0.03 \\
Health Practices & Mariners & -0.01 & 0.04 & $-0.36(0.016)$ & -0.21 & 0.06 \\
& Managers & $0.38(0.010)$ & -0.19 & -0.10 & $-0.42(0.005)$ & -0.13
\end{tabular}

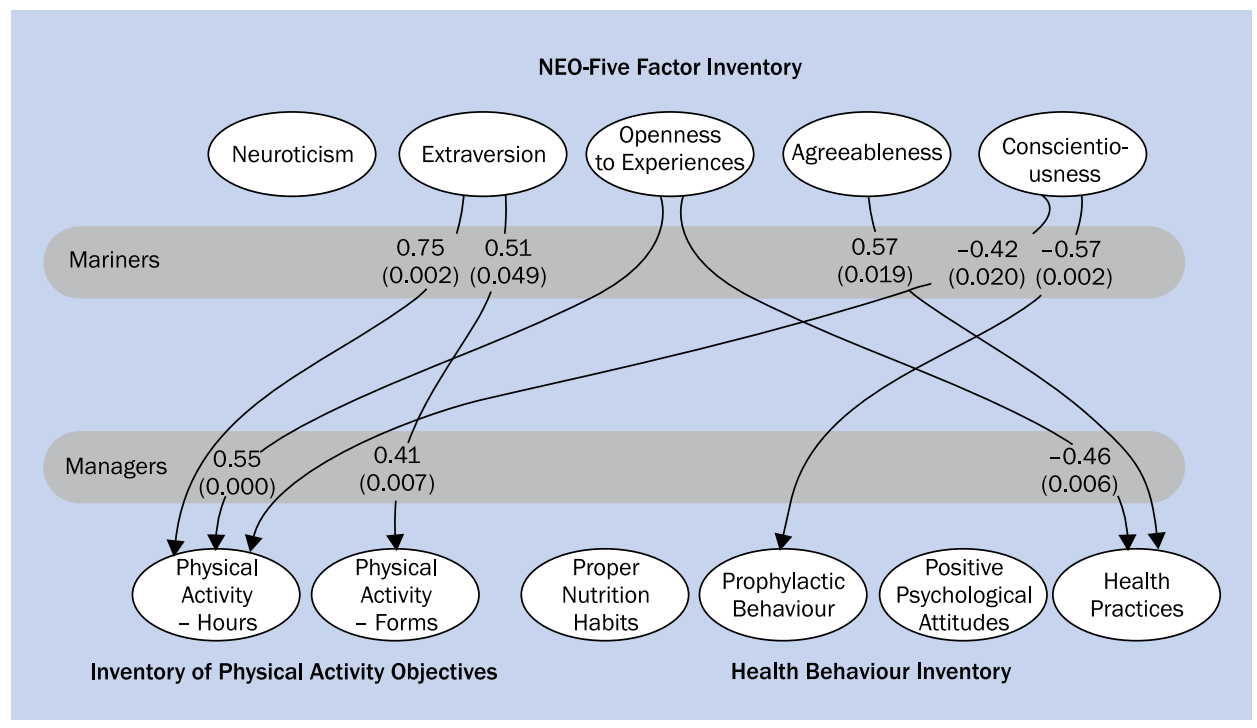

Figure 2. Multiple regressions: the impact of personality profiles on health behaviours

In the next stage, we conducted a multiple regression analysis of personality profiles (explanatory variables) for every health behaviour (explained variables). Regressions performed separately for mariners and managers revealed many interesting correlations (Fig. 2).

Fitting, statistically significant multiple regression models for the dependent variables of personality profiles were obtained for:
- Number of hours of PA: in case of mariners this explained $45 \%$ of variability $(F=5.71, p=0.001)$, in case of managers $52 \%$ of variability $(F=4.71, p=0.005)$;

- Number of forms of PA of managers explained $36 \%$ of variability $(F=4.35, p=0.003)$;

- Prophylactic behaviours of mariners explained $44 \%$ of variability $(F=4.04, p=0.008)$;

- Health practices of mariners explained $40 \%$ of variability $(F=3.48, p=0.015)$. 
Indicator Variables in Regression were used to assess the differences between groups in terms of the strength of impact $(\beta)$ of each personality trait on health behaviours. It turned out that there was a difference between mariners and managers ( $\beta=0.26, p=0.199)$ in terms of the impact of conscientiousness on prophylactic behaviours (dummy variable: $t=2.86, p=0.006$ ). Differences were observed also for the impact of extroversion on the examined groups (managers: $\beta=0.27, \mathrm{p}=0.068$, dummy variable: $\mathrm{t}=2.15$, $p=0.036$ ) and conscientiousness (managers: $\beta=0.10$, $\mathrm{p}=0.555$, dummy variable: $\mathrm{t}=2.75, \mathrm{p}=0.008$ ) on the number of PA hours per week. The last observed difference between the values of $\beta$ regarded the influence of agreeability on health behaviours - the relationship was negative among managers $(\beta=-0.25, p=0.081)$, and positive among mariners (dummy variable: $\mathrm{t}=2.94, \mathrm{p}=0.005$ ).

\section{DISCUSSION}

The analysis of the results of the research regarding personality profiles and health behaviours among mariners and managers revealed lack of statistically significant differences between the compared groups and an oscillation of the results at average or moderately high levels. This fact indicates lack of clear differences in personality profiles of managerial staff, independent of the particularity of the place of performance of the tasks and the group of workers. Taking into account the results for seafarers, one needs to note the highly adaptive personality profile for the character of work. Increased levels of extroversion and conscientiousness combined with relatively low levels of neuroticism allows the officers of merchant navy to properly handle the difficult situations at sea, and form satisfactory interpersonal relationships with subordinates. This happens in the particularly difficult situation of social and physical isolation that is known to promote interpersonal conflicts $[5,11]$. It is important to stress that the obtained results are in line with previous research carried out with a group of 300 mariners, differentiated in terms of the character of work at the sea - they suggest an analogical personality profile, confirming the satisfactory preparation of seafarers for their job [43].

The analysis of correlations between personality features and health behaviours revealed interesting relationships. A positive correlation between the extroversion dimension and the number of hours of undertaken PA, a positive relationship between openness to experience and the number of forms of undertaken PA, and a negative relation between openness to experience and health behaviours were observed for the investigated group of merchant navy officers. Extroversion as a personality trait determines the levels of activity, energy and the ability to experience positive emotions [25] and therefore is considered to be an important predictor of good health [27]. It promotes activity, also physi- cal, engaging in sports and behaviours aimed at maintaining a good physical condition. On the other hand, high levels of extroversion may be correlated with excessive search for new experiences, need for stimulation and sensations, which may result in engaging in risky behaviours that are classified as anti-health behaviours [34, 35]. The moderate levels of extroversion of the investigated group are tightly correlated with engaging in health behaviours and PA that do not belong to the risk categories. Such results are tightly related to the aforementioned previous research regarding the relationships between the personality and temperament of seafarers and their subjective perceptions of quality of their lives [43]. A positive correlation was observed in the study between extraversion and the subjective perception of one's own physical health. Also openness to experience, in subject literature, is usually associated with health behaviours [30]. However, overly high levels of it may be associated with the need for experimenting and search for new experiences [31]. According to the results of our study, these moderate levels of openness to experiences are positively correlated with the need to search for new forms of PA, but negatively correlated with the need for new health behaviours, which might be characterised by higher conventionality among the officers. Interestingly, previous research on a different group of seafarers did not reveal the correlation between openness and the perception of physical health, in contrast to the dimension of conscientiousness, which was positively correlated with that variable [43]. Therefore, it seems valuable to carry out an in-depth analysis extending beyond the search of predictive correlations, which is presented below.

Comparative analysis regarding mariners and managers indicated that the personality features had a higher impact in the control group. In the group of managers as well as seafarers, extroversion was positively correlated with the number and forms of undertaken physical activities as well as a positive psychological attitude. The dimension of openness to experiences was positively correlated with the number of forms of activity. It is important to note that among the managers and seafarers, both personality dimensions were at average or moderate levels, which favours the undertaking of health behaviours [27]. However, significant relationships between conscientiousness as well as agreeability and health behaviours were also observed in the investigated group of managers. The levels of agreeability were positively correlated with positive psychological attitude and negatively correlated with health behaviours. Levels of conscientiousness were positively correlated with the number of hours devoted to PA, number of forms of undertaken $\mathrm{PA}$, and negatively correlated with unhealthy habits. One needs to take into account the situational factors associated with the specifics of the seafarers' work when considering the observed differences between the groups 
in terms of the correlations of personalities and health behaviours. As mentioned in the introduction, personality and the associated values and needs can be an important, but not the sole, predictor of health behaviour. The important role of lifestyle is also highlighted [23], which is different in the two groups. The activities of mariners are significantly limited by the fact that they are only periodically able to undertake PA with ease. In contrary to the investigated group of managers, the mariners are often only able to undertake the PA when at home, ashore. Subject literature [6] suggests that sport may be an important factor supporting the seafarers both physically and psychologically in the process of coping with burdens associated with working at sea, improving their subjective perception of psychological wellbeing.

The main goal of the presented study was to look for personality predictors of health behaviours undertaken by the seafarers. The results confirmed the merit of the undertaken task, and confirmed significant personality determinants of pro-health behaviours one engages in [24]. Though the obtained relationships confirm the initial correlation analysis, they reveal the influence of other personality variables. Four significant regression models were obtained for the investigated group of seafarers. They included variables such as: number of hours devoted to PA, number of forms of PA, prophylactic behaviours and health behaviours. In case of the group of managers, significant correlations were observed also for the number of hours and forms of PA as well as health behaviours. In the group of officers, extroversion and conscientiousness were significant predictors of the number of hours spent on PA. High levels of extroversion co-occurring with low levels of conscientiousness determined the increase of the number of hours devoted to PA. Whereas positive influence of extroversion raises no doubts when taking into account the described positive relations between this personality variable and activity of an individual, the negative influence of conscientiousness may raise some doubts. Previous research investigating the relationships between conscientiousness and health behaviours suggests that its high levels are associated with self-discipline and engagement in caring for one's health, e.g. through participation in PA or undertaking preventive behaviours $[28,29]$. One can therefore wonder why this relationship was the opposite in the case of the seafarers. It is important to mention here that the low levels of conscientiousness turned out to also be a significant predictor of prophylactic behaviours in the group of officers. Trying to explain such results, it comes to mind that they might treat PA as a form of avoidance of other, more relevant tasks, duties or obligations. Low levels of conscientiousness may encourage seafarers to undertake escapist forms of coping with stress e.g. manage with the overload of duties through engaging in accessory activities such as sport. One needs to emphasize that PA is often undertaken by the seafarers only when they are at home, where unsolved problems and home duties await them. The feeling of being overloaded with roles and pressure, often reported by seafarers $[3,44]$, may lead them to attempt to escape through PA. However, is it possible to find a similar explanation for the relationship between low conscientiousness and prophylactic behaviours? It is known that high levels of physical and psychological burden imposes the necessity of frequent medical examinations on the seafarers $[2,5]$, which might result in an external control of prophylactic behaviours and therefore not require high levels of conscientiousness from the mariners in that regard.

The groups significantly differed in terms of the undertaken health behaviours. In case of the seafarers, health behaviours were positively determined by the levels of agreeability. In case of the managers it was negatively correlated with the levels of experience. Therefore it can be stated that high levels of agreeability of seafarers encourages undertaking suitable health behaviours that may aim at improvement of their health and psychological wellbeing in the face of the many threats associated with the peculiarities of their job [18]. During the process of preparation for work, officers and their subordinates become acquainted with the challenges and risks arising from the character of their work, and they become aware of the necessity to properly, constructively cope with stress, which includes taking care of one's health [45]. It is important to remember that in case of seafarers, undertaking the appropriate health behaviours is important from the point of view of limited access to medical care on the ship during a cruise.

\section{CONCLUSIONS}

Undertaking pro-health behaviours was closely correlated with selected dimensions of personality, especially extroversion, openness to experiences and conscientiousness, in both investigated groups of mariners and managers. However, these relationships seem to differ between the groups, due to the influence of other, objective factors determined by the peculiarities of their work and lifestyle - this was especially visible in case of the seafarers. However, the conducted analyses also make one think that the undertaking of PA by mariners may comprise an important factor limiting the negative effects of stressors associated with working at sea. As such it may play a preventive role, counteracting the vast amount of negative consequences of working at sea, both physical and psychological. This justifies the suggestions about equipping ships (not only passenger, but also freight) with rooms suitable for physical exercise, gyms that could successfully stimulate the physical and psychological wellbeing of seafarers during their work and stay at the sea. 


\section{REFERENCES}

1. Ogińska-Bulik N. Zachowania ryzykowne i szkodliwe dla zdrowia. Wyd. AHE, Łódź 2010.

2. Jaremin B. Zgony polskich marynarzy i rybaków podczas pracy na morzu w latach 1960-1999: analiza zjawiska i wpływu środowiska pracy ze szczególnym uwzględnieniem orzecznictwa lekarskiego i możliwości prewencji. Akademia Medyczna w Gdańsku, Gdańsk 2005.

3. Peplińska A. Małżeństwo a specyfika pracy marynarzy - perspektywa psychologiczna. Oficyna Wydawnicza Impuls, Kraków 2011.

4. Leka S. Psychosocial hazards and seafarers health: priorities for research and practise. Int Marit Health 2004; 55: 137-154.

5. Borucki Z. Stres i przystosowanie w zawodzie marynarza. Przegl Psychologiczny 1972; 2: 63-74.

6. Carotenuto A, Molino J, Fasanaro AM, Amento F. Psychological stress in seafarers: a review. Int Marit Health 2012; 63: 188-194.

7. Leszczyńska I, Jeżewska M. Psychosocial burden among offshore drilling platform employees. Int Marit Health 2010; 61: 159-157.

8. Jeżewska M, Iverson R. Stress and fatigue at sea versus quality of life. Int Marit Health 2012; 63: 106-115.

9. Leszczyńska I, Jeżewska M, Jaremin B. Work-related stress at sea. Possibilities of research and measures of stress. Int Marit Health, 2007; 58: 93-102.

10. Peplińska A, Rostowska T. Quality of life and relations between work and family. Acta Neuropsychologica 2013; 11: 77-92.

11. Plopa M. Stres w izolacji morskiej: psychospołeczne uwarunkowania. Wyd. UG, Gdańsk 1996.

12. Peplińska A, Jeżewska M, Leszczyńska I, Połomski P. Stress and the level of perceived anxiety among mariners: the mediating role of marital satisfaction. Int Marit Health 2013; 64: 221-225.

13. Peplińska A, Jeżewska M, Leszczyńska I, Połomski P. Purpose in life and work-related stress in mariners. Mediating role of quality of marriage bonds and perceived anxiety. Int Marit Health 2014; 65: 87-92.

14. Jeżewska M. Osobowość dowódcy/kapitana jako lidera w pracy na morzu. Kierowanie załogą i pasażerami. In: Jeżewska M, Jaremin B (eds.). Promocja zdrowia w morskim środowisku pracy. Szkolenie liderów. AM Gdynia 2011, 104-109.

15. Johnsen $B J$, Meeùs $P$, Meling $J$ et al. Cultural differences in emotional intelligence among top officers on board merchant ships. Int Marit Health 2012; 63: 90-95.

16. Peplińska A, Lipowski M, Nieckarz Z. Career and professional development: challenges for employees and modern organizations. Pol J Social Science 2011; 6: 75-100.

17. Kuoppala J, Lamminpää A, Liira J, Vainio H. Leadership, job well-being, and health effects: a systematic review and a meta-analysis. J Occup Environmental Med 2008; 50: 904-915

18. Carotenuto A, Fasanaro AM, Molino I et al. The Psychological General Well-Being Index (PGWBI) for assessing stress of seafarers on board merchant ships. Int Marit Health 2013; 64: 215-220.

19. Boguszewski R. Polacy o swoim zdrowiu oraz prozdrowotnych zachowaniach i aktywnościach. In: Hipsz N, Boguszewski R (eds.). Raport CBOS-Zdrowie w wymiarze osobistym i instytucjonalnym. Samooceny, zachowania, opinie. CBOS, Warszawa 2012; 10-23.

20. Global Recommendations on Physical Activity for Health. World Health Organisation, Geneva 2010.

21. Bortz WM. Biological basis of determinants of health. Am J Public Health 2005; 95: 389-393.

22. Heikkilä K, Fransson El, Nyberg ST et al. Job strain and health-related lifestyle: findings from an individual-participant meta-analysis of 118000 working adults. Am J Public Health 2013; 103: 2090-2097.

23. Woynarowska B. Edukacja zdrowotna. PWN, Warszawa 2008.

24. Kinnunen M-L, Metsäpelto RL, Feldt T et al. Personality profiles and health: Longitudinal evidence among Finnish adults. Scand J Psychology 2012; 53: 512-522.
25. Costa PT, McCrae RR. Four ways Five Factors are basic. Personality and Individual Differences 1992; 13: 653-665.

26. Costa PT, McCrae RR, Norris AH. Personal adjustment to aging: longitudinal predictions from neuroticism and extraversion. J Gerontology 1981; 36: 78-85.

27. Chapman BP, Roberts B, Duberstein P. Personality and longevity: knowns, unknowns, and implications for public health and personalized medicine. J Aging Res 2011; DOI:10.4061/2011/759170.

28. Bogg T, Roberts BW. The case for conscientiousness: evidence and implications for a personality trait marker of health and longevity. Ann Behav Med 2013; 45: 278-288.

29. de Bruijn GJ, de Groot R, van den Putte B, Rhodes R. Conscientiousness, extroversion, and action control: comparing moderate and vigorous physical activity. J Sport Exercise Psychology 2009; 31: 724-742.

30. Ferguson E, Bibby PA. Openness to experience and all-cause mortality: a meta-analysis and requivalent from risk ratios and odds ratios. $\mathrm{Br}$ J Health Psychology 2012; 17: 85-102.

31. Terracciano A, Lockenhoff CE, Crum RM, Bienvenu OJ, Costa PT, Jr. Five-factor model personality profiles of drug users. BMC Psychiatry 2008; DOI: 10.1186/1471-255X-8-22.

32. Goodwin RD, Friedman HS. Health status and the five factor personality traits in a nationally representative sample. J Health Psychology 2006; 11: 643-654.

33. Hall AP, Fong GT, Epp $\sqcup$. Cognitive and personality factors in the prediction of health behaviors: an examination of total, direct and indirect effects. J Behav Med 2013; DOI: 10.1007/s10865-013-9535-4.

34. Kotov R, Gamez W, Schmidt F, Watson D. Linking “big" personality traits to anxiety, depressive, and substance use disorders: a meta-analysis. Psychological Bull 2010; 136: 768-821.

35. Zietsch BP, Verweij KJH, Bailey JM, Wright MJ, Martin NG. Genetic and environmental influences on risky sexual behaviour and its relationship with personality. Behavior Gen 2010; 40: 12-21.

36. Tok S. The big five personality traits and risky sport participation. Social Behav Personality 2011; 39: 1105-1112.

37. Lipowski M, Bieleninik $Ł$. Personality superfactors and healthy behaviors of professional athletes. Curr Issues Personality Psychology 2014; 2: 1-12.

38. Roberts BW, Kuncel N, Shiner RN, Caspi A, Goldberg LR. The power of personality: The comparative validity of personality traits, socio-economic status, and cognitive ability for predicting important life outcomes. Perspectives Psychological Science, 2007; 2: 313-345.

39. Lee WE, Wadsworth ME, Hotopf M. The protective role of trait anxiety: a longitudinal cohort study. Psychological Med 2006; 36: 345-351.

40. Raynor DA, Levine $\mathrm{H}$. Associations between the five-factor model of personality and health behaviors among college students. J Am College Health 2009; 58: 73-82.

41. Zawadzki B, Strelau J, Szczepaniak P, Śliwińska M. Inwentarz osobowości NEO-FFI Costy i McCrea. Adaptacja Polska. Podręcznik. Pracownia Testów Psychologicznych Polskiego Towarzystwa Psychologicznego, Warszawa 1998.

42. Juczyński Z. Narzędzia pomiaru w promocji i psychologii zdrowia. Warszawa: Pracownia Testów Psychologicznych Polskiego Towarzystwa Psychologicznego, Warszawa, 2001.

43. Jeżewska M, Leszczyńska I, Grubman-Nowak M. Personality and temperamental features vs. quality of life of Polish seafarers. Int Marit Health 2013; 64: 101-155.

44. Jeżewska M, Leszczyńska I, Jaremin B. Work-related stress at sea self estimation by maritime students and officers. Int Marit Health 2006; 57: 66-75.

45. Jeżewska M. Dobór ludzi do pracy na morzu. Psychologia zachowań ludzkich. In: Jeżewska M, Jaremin B (eds.). Promocja zdrowia w morskim środowisku pracy. Szkolenie liderów. AM Gdynia, 2011; 75-82 